\title{
Role of Government to Enhance Digital Transformation in Small Service Business
}

\author{
Chun-Liang Chen ${ }^{1}\left(\mathbb{D}\right.$, Yao-Chin Lin ${ }^{2}$, Wei-Hung Chen ${ }^{2} \mathbb{D}$, Cheng-Fu Chao ${ }^{3} \mathbb{D}$ and Henry Pandia ${ }^{2, *(\mathbb{D})}$ \\ 1 Graduate School of Creative Industry Design, National Taiwan University of Arts, \\ New Taipei City 22058, Taiwan; jun@ntua.edu.tw \\ 2 Department of Information Management, Yuan Ze University, Taoyuan City 32003, Taiwan; \\ imyclin@saturn.yzu.edu.tw (Y.-C.L.); s999202@mail.yzu.edu.tw (W.-H.C.) \\ 3 National Association of Small and Medium Enterprises, Taipei City 10646, Taiwan; frank_chao@nasme.org.tw \\ * Correspondence: pandiahenry@unai.edu
}

Citation: Chen, C.-L.; Lin, Y.-C.; Chen, W.-H.; Chao, C.-F.; Pandia, H. Role of Government to Enhance Digital Transformation in Small Service Business. Sustainability 2021, 13, 1028. https://doi.org/10.3390/ su13031028

Academic Editor: Joseph K. Nwankpa Received: 26 November 2020

Accepted: 16 January 2021

Published: 20 January 2021

Publisher's Note: MDPI stays neutral with regard to jurisdictional claims in published maps and institutional affiliations.

Copyright: (c) 2021 by the authors. Licensee MDPI, Basel, Switzerland. This article is an open access article distributed under the terms and conditions of the Creative Commons Attribution (CC BY) license (https:// creativecommons.org/licenses/by/ $4.0 /)$.

\begin{abstract}
In the digital economy era, small service business struggle to compete in a rapidly changing and dynamic market. Therefore, through digital transformation (DT), small service business seek to increase their competitive advantage, improve business performance, and achieve business growth. Having limited resources and capabilities, small service business must deal with several barriers and challenges. This study aims to discover the barriers, and the roles of government, for digital transformation in small service business. This study applied a qualitative approach involving semistructured in-depth interviews with top management of small service business. Then, we employed the content analysis method to examine interview data and construct a model. This research reveals four main barriers to digital transformation in small service business: lack of funding, lack of digital capability, lack of human resources, and technical barriers. We found there are four government roles for supporting digital transformation in small service business: build a digital platform for small service business, promote mobile/digital payment, provide digital training, and build a digital collaboration ecosystem. Additionally, based on this study's findings, a model for barriers and government support of digital transformation in small service business is presented. This study contributes to the conceptual framework and management implications in the digital transformation field. The study's findings provide insights to practitioners and suggest that the government could alter the current policies and programs to support digital transformation in small service business.
\end{abstract}

Keywords: small service business; digital transformation; barriers; government's role in digital application; digital technology

\section{Introduction}

Digital transformation (DT) has become a new approach for many firms to gain competitive advantages in a context of intense and dynamic market competition. Many organizations have applied digital transformation, with a positive impact on organization business performance [1-5] and productivity [6], leading to an increase in their superiority [7-9]. Digital technologies and the internet have remarkably transformed how the market works by reducing costs for searching, transportation, reproduction, transactions, and seeking new market opportunities for "higher market efficiency" [10]. Digital technologies applications give innovators and entrepreneurs opportunities for a new broader boundary for value creation and value capture [11] and increase the intention to become an entrepreneur [12]. Digital technologies have become drivers in the emergence and growth of micro and small businesses [13-15]. Moreover, digital technologies increase business survival in a time of crisis. During the Covid-19 outbreaks, many businesses experienced a rapid increase in online transactions [16].

Despite the positive impact of digital transformation, when adopting digital transformation an organization must deal with several issues. Digital transformation involves an 
investment of enormous amounts of money, without any guarantee of return [1]. Therefore, to increase the chance of success, researchers have suggested organizations apply technologies to create innovation in products, services, processes [17], and business models [1,7]. Finally, organizations should consider their business orientation before adopting digital transformation, as well as their business strategies. Although digital transformation is a challenging process, it is a "competitive necessity" for many organizations to ensure their survival through business disruption [18]. Nevertheless, the utilization rate of digital transformation among small- and medium-sized enterprizes (SMEs) is still very low $[14,19]$.

Many studies have been conducted on digital transformation in the last decade. However, most of the studies have been in fields related to large businesses, manufacturers, industrial, and data analytics [20,21]; few have been in small service business [22]. Small businesses have higher digital innovation barriers than large businesses due to their limited resources and lack of capabilities [23]. Despite sharing several characteristics with the manufacturing industry, the service industry also has various characteristics that distinguish it from others [24]. These characteristics determine the innovation activities in a service organization [25]. Therefore, a digital transformation study in small service business is necessary to fill the knowledge gap.

Small businesses have many limitations, including limited access to funding, lack of managerial skill, lack of technology capabilities, limited access to raw materials, and restricted infrastructure availability, that restrain them from expanding and growing their business [26,27]. Many studies have been conducted to examine the government's roles in improving small businesses' productivity and growth, and they concluded that the government's roles in supporting small businesses are indispensable. Conversely, the study of government roles in the process of digital transformation is limited. Since small businesses mostly depend on government policy and programs, a digital transformation study in small business must include government roles to achieve a comprehensive view.

Due to their contribution to the national economy, the government is concerned with small service business competitiveness, business performance, and growth. Therefore, the government needs to enhance the implementation of digital transformation in small service business. However, according to previous research [14,19], the digitalization level in small service business is still low. Small service business need proper policies, programs, and support from the government to implement digital transformation successfully. However, how the government can help small service business to implement digital transformation is still unclear. A study of government roles to help small service business is needed to increase the alignment of government policies and programs with small service business demand while implementing the digital transformation process. This study was conducted to find the policies and programs the government could create to help digital transformation in small service business, and to determine how to spend the government annual budget to maximize impact to small service businesses so they can achieve the objective of digital technologies adoption.

This study explores and contributes a comprehensive digital transformation concept in small service business based on a literature review and the above explanation. The study aimed to answer the following research questions: [1] What are the main barriers and challenges of digital transformation in small service business? [2] What is the role of the government in supporting digital transformation in small service business?

This paper is structured as follows. Section 2 contains a literature review of digital transformation and small business. In Section 3, the research method explains the details of data collection and subject selection. Next, Section 4 presents the data, findings, and discussion. Section 5 concludes the results and discusses managerial implications, research limitations, and future research. 


\section{Literature Review}

\subsection{Small Business and Government Policy}

Each country has its own SME definition, reflecting its economic characteristics [28]. Although it is challenging to establish a global definition [29], categorizing SMEs based on the number of employees, turnover, assets, or combinations of those criteria is quite acceptable globally. In Taiwan, an SME is defined as a business entity with less than 100 regular employees [30]. SMEs have contributed to the nation's economy in many countries, and in many cases have become the backbone of the nation's economy [28,30]. SMEs participate in the national economy by creating jobs [31-33], increasing gross domestic product (GDP), and developing and sustaining national economies [34,35].

In the resource-based view (RBV) of a firm, small businesses have limited resources and capabilities. Therefore, a small business often cannot compete with larger firms using their solitary resources and capabilities. Realizing the significance and vitality of SMEs' roles, many governments provide specific programs, funding, policies, and counseling in national economic plans to support SME growth and help small businesses gain a competitive edge [36,37].

Small businesses with limited resources and inadequate capabilities can accomplish digital transformation by adopting third-party digital platform services [38]. Organizations suggest SMEs increase their capabilities by learning from other partners in collaboration [39]. The government has a role in creating policies, programs, and rules that help small businesses deal with their limited resources and inadequate capabilities [36,37,40,41]. As policymakers, the government can develop and strengthen policies and programs to support small businesses' digital transformation agendas, by creating specific policies, support and counseling initiatives, customized training programs, and collaboration ecosystems [42]. In conclusion, small businesses can improve their business performance, increase productivity, and achieve business growth through digital transformation by adopting others' digital platform services, increasing their capabilities, and obtaining government support.

The service industry and other industries have different characteristics [24] that determine innovation activities [25]. Ettlie and Rosenthal [43] studied service and manufacturer companies and found significant differences in how organizations in these two sectors innovate and create new products/services. Manufacturers identify customers' desires and expectations and report the need for new strategies. Services exploit new ideas for new products/services and covert innovation into success as an alternative to formal innovation. In the service industry, organizations interact with customers as an inseparability of the production process, to inquire regarding customer needs and then apply this need in service products [44]. Previous studies [25] have found that several necessary innovations occur when an interaction between customers and co-production is high. Therefore, in the service industry, customers can be considered as a firm's "part-time" employees who participate in the service process, and value co-creation of new service offerings [45,46]. Recently, organizations have begun to use customers' evaluations of products as feedback for innovation and service promotion, by sharing customer reviews and experiences on social media.

The digitization level in service industries varies globally [14,28,47,48]. In Taiwan, SMEs contribute $29.59 \%$ of all enterprises' total annual sales, and represent $78.41 \%$ of all employed persons. The majority of SMEs in Taiwan are concentrated in service industries, with $47.27 \%$ of SMEs in wholesale and retail trade. Accommodation and food services activities contribute about $11.16 \%$ of GDP [30]. The wholesale and retail trade is the second largest contributor to Taiwan's GDP, accounting for $10.2 \%$ of the total GDP, and many of Taiwan's wholesalers are small- to medium-sized businesses. Compared to other sectors, the level of digitalization of the service sector is low. There are many areas to digitize in service sectors, especially in internal processes and the workforce [14]. 


\subsection{Digital Transformation}

Digital transformation is a "systematic approach," "highly complex" and a "companywide endeavor" [49] to implement digital technologies innovatively, "that can substantially shape a company and its operations" [50]. Digital transformation provides an organization with a chance to rethink customers' values to gain competitive advantages [51] and enhance the organization's business performance [18,49]. Digital transformation focuses on increasing harmony among organization business functions to generate improvement in products, services, and business models by adopting digital technologies as leverage [49].

Drivers of digital transformation refer to factors that enable and influence an organization to adopt digital transformation into their business [52]. According to Wade's [18] report, technologies such as mobile tools and applications, social media, Internet of Things (IoT), analytics tools and applications, platforms for communication and sharing data, and collaboration applications have a significant role in digital transformation. Therefore, digital technologies are considered as one of the main digital transformation drivers. On the contrary, Kane et al. [53] argued that solely applying digital technologies is not enough to drive digital transformation. A firm must have sufficient digital capabilities, digital strategies, culture, and talent development to ensure successful digital transformation. Other studies have found several attributes, such as customer behavior, customer expectations, digital shifts in the industry, changes in the competitive landscape [54], and regulative changes [55] can be drivers of digital transformation. Moreover, digital transformation can also be driven by opportunities to increase business performance, such as profitability and new revenue growth, customer satisfaction, increasing operational efficiency, convenience and high-quality technical standards, increasing business agility, and increasing employee productivity and competitive advantage [56].

Although digital transformation has positively impacted business performance, productivity, and growth, many obstacles can prevent a small business from adopting and implementing digital technologies. The barriers can vary considerably across different industries, firm sizes, firm cultures, market competition levels, countries, business environments, and so forth. [57]. Previous studies have identified several obstacles to technology adoption in a small business: technical technology barriers, regulation barriers, data barriers, organizational barriers, culture and management barriers, economic and financial barriers, and market barriers [58].

Studies of digital transformation have been a significant trend among researchers in the last five years [20,59]. Several approaches to digital transformation studies have been applied in the literature. These frameworks have concentrated on a specific concept and suit for a specific case. Table 1 shows the frameworks of digital transformation that have been proposed by previous studies.

Table 1. Frameworks of digital transformation.

\begin{tabular}{|c|c|c|c|c|}
\hline No. & Frameworks & Dimensions & Description & Ref. \\
\hline 1 & $\begin{array}{l}\text { Integrated Methodological } \\
\text { Framework for Digital } \\
\text { Transformation Strategy }\end{array}$ & $\begin{array}{l}\text { Apply nine elements of IT } \\
\text { Governance Practice and } \\
34 \text { processes }\end{array}$ & $\begin{array}{l}\text { The framework provides specific } \\
\text { guidelines to help organizations } \\
\text { formulating, implementing, and } \\
\text { monitoring their } \\
\text { transformation strategies. }\end{array}$ & {$[60]$} \\
\hline 2 & $\begin{array}{l}\text { Digital Transformation } \\
\text { Success Framework }\end{array}$ & $\begin{array}{l}\text { Strategy, integration, impact, } \\
\text { stakeholder, value, skills, goals, } \\
\text { and outcome }\end{array}$ & $\begin{array}{l}\text { The framework is useful to identify } \\
\text { benefit achieved by digital } \\
\text { transformation and indicate } \\
\text { possibilities of gaining success with } \\
\text { digital transformation }\end{array}$ & [61] \\
\hline 3 & $\begin{array}{c}\text { Digital } \\
\text { Innovation } \\
\text { Strategy Framework }\end{array}$ & $\begin{array}{l}\text { User experience, value proposition, } \\
\text { digital evolution scanning, skills, } \\
\text { and improvisation }\end{array}$ & $\begin{array}{l}\text { The framework provides a firm with a } \\
\text { holistic view of digital innovation } \\
\text { when navigating the rapidly changing } \\
\text { digital innovation landscape. }\end{array}$ & [62] \\
\hline
\end{tabular}


Table 1. Cont

\begin{tabular}{|c|c|c|c|c|}
\hline No. & Frameworks & Dimensions & Description & Ref. \\
\hline 4 & Digitalization Piano Framework & $\begin{array}{l}\text { Business Model } \\
\text { Structure } \\
\text { People } \\
\text { Processes } \\
\text { IT Capability } \\
\text { Offering } \\
\text { Engagement }\end{array}$ & $\begin{array}{l}\text { The framework was built by dividing } \\
\text { the organization's value chain into } \\
\text { seven critical elements and using the } \\
\text { main focus of digital } \\
\text { business transformation. }\end{array}$ & [18] \\
\hline 5 & $\begin{array}{l}\text { Framework for Digital } \\
\text { Transformation Strategies }\end{array}$ & $\begin{array}{l}\text { Use of technologies, changes in } \\
\text { value creation, structural changes, } \\
\text { and financial aspects. }\end{array}$ & $\begin{array}{l}\text { Framework formulates a digital } \\
\text { transformation strategy to serve as a } \\
\text { central concept to integrate the full } \\
\text { coordination, prioritization, and } \\
\text { adoption in digital transformations } \\
\text { within a firm. }\end{array}$ & {$[50]$} \\
\hline 6 & $\begin{array}{l}\text { Cognizant's Digital } \\
\text { Transformation Framework }\end{array}$ & $\begin{array}{l}\text { Customer, Product, Processes and } \\
\text { Systems, and Organization }\end{array}$ & $\begin{array}{l}\text { Organizations use the framework to } \\
\text { develop organization's digital vision } \\
\text { and build a new business model based } \\
\text { on digital opportunities. }\end{array}$ & [63] \\
\hline 7 & $\begin{array}{l}\text { The Digital Reinvention } \\
\text { framework }\end{array}$ & $\begin{array}{l}\text { New Ways to Work (actionable } \\
\text { insights, responsive operations), } \\
\text { New Expertise (orchestrated } \\
\text { ecosystem, human resources), New } \\
\text { Focus (market/customer activation } \\
\text { business models) }\end{array}$ & $\begin{array}{l}\text { The framework works by using the } \\
\text { concept to gain success in digital } \\
\text { business. Organizations need to } \\
\text { pursue a new strategic focus, establish } \\
\text { new ways of working, and build } \\
\text { new expertise. }\end{array}$ & [64] \\
\hline 8 & $\begin{array}{c}\text { Framework for Dimensions of } \\
\text { Digital Transformation }\end{array}$ & $\begin{array}{l}\text { Go-To-Market } \\
\text { Engagement } \\
\text { Operations } \\
\text { Organization }\end{array}$ & $\begin{array}{l}\text { The framework that uses the main } \\
\text { four critical areas to focus on during } \\
\text { digital transformation then integrates } \\
\text { it to other business parts. }\end{array}$ & [65] \\
\hline
\end{tabular}

Adopting digital transformation is unavoidable. An organization must respond to the challenges of globalization and urbanization of economic activities. Organizations must modernize by integrating their activities with a new digital ecosystem. Organizations have an opportunity to develop solutions to complex problems through digital transformation [66]. However, to succeed in digital transformation, in addition to applying the right framework, an organization must have digital readiness - the desire and willingness to implement digital technologies and create innovation to achieve its objectives $[67,68]$-as well as sufficient digital capabilities [69,70] and sufficient resources and funding [21].

The digital transformation frameworks listed in Table 1 were developed by assuming that the organization has sufficient digital capabilities, resources, and funding. Since small businesses tend to have insufficient digital capabilities, resources, and funding, applying the frameworks demands additional support. Small businesses cannot implement digital transformation without support from external parties. Therefore, a study of how the government can support small businesses in digital transformation adoption is needed.

In previous studies [52], most researchers have focused on digital transformation in the following areas: customer experience, the business model, operational processes, employees, culture, and infrastructure. This study uses Cognizant's Digital Transformation Framework to analyze digital transformation implementations in selected cases. Therefore, the rest of the literature review will consider the dimensions associated with the selected framework.

\subsubsection{Organization}

Organizational change is the basis of digital business transformation. Organizational change requires awareness of what must be transformed, and a strategic approach to making the necessary changes. Organizational change is required for adaptation to new 
market competition and changing customer demands [18]. Nguyen et al. [71] found that organizational change is a determinant factor in creating an "adoption environment" to ensure digital technology implementation success in a small business. The combination of organizational change and adoption of digital technologies can give an organization the opportunity to increase performance in many areas, such as improved efficiency and reduced costs, increased revenue, more practical knowledge collection, faster and more successful innovation, enhanced customer engagement and customer service, sharing and using, and lastly, the ability to survive despite digital disruption of the industry [18].

Corver and Elkhuizen [63] defined organizational transformation as digital collaboration and innovation, digital skills and a virtual workforce, and a dynamic partner ecosystem. In addition to providing a chance to create a novel business model, digitalization across the various areas also gives small businesses the opportunities to create a new form of collaboration [39,72,73] beyond the organization's borders [63]. In the context of innovation, collaboration can involve a partnership between small businesses in the same industry-to generate market demand, encourage the business ecosystem, and create products/services; or in different industries-to pursue mutual objectives with fewer conflicts of interest [39].

To succeed in digital transformation, organizations must increase their digital transformation capacity [74]. However, due to limited business resources, organizations must focus on the factors they consider a priority. Kwon and Park [74] found that human factors significantly impact the digital transformation capacity of an organization. Organizations need to increase their employee's skills. Organizations expect employees to be involved in continuous learning and must form a team with the right blend of skills required by different projects [75]. A small business must adopt a "learning culture" for digital transformation of operations [76]. Furthermore, employees must have the ability to work with virtual workforce technologies and tools, such as cloud services, mobile apps, document collaboration, and so forth, that give employees the ability to work remotely from anywhere but remain connected to collaborative teams.

Digital transformation also changes organizations by creating a dynamic partner ecosystem. In this ecosystem, an organization must have agility in building partnerships across industries, as well as with customers. Therefore, an organization must increase its capability to build network relationships. Network relationships refer to the organization's capability to interact with other parties, such as other firms and customers, build understanding through communication and coordination, and increase the level of trust [77]. A study by Beliaeva et al. [78] suggested a small business that expects greater digitalization should establish a partnership in three main areas: funding agencies and investors, social capital and networking, and knowledge-based actors.

\subsubsection{Product}

Product has a significant role in digital transformation. Therefore, organizations consider product innovation as key to gaining competitive advantages [79]. Digital technologies play a significant role as an enabler in the process of product innovation. Firms with superior technology capabilities can transform traditional products, services, and customer offerings into digital offerings when adopting digital transformation [80]. Organizations apply innovation to products or services through digitalization products or integrating digital technologies into the products.

Digital technologies enable organizations to achieve product digitization using two methods: digitalized products and integrating digital technologies into products. Digitalized products refer to developing digital products as digital versions of existing products or brand-new digital products [81]. Integrated digital technologies refers to embedding digital technology into existing products or services; for instance, adding a smart sensor for collision avoidance into a car, or giving free WiFi at Starbucks outlets [82]. A small business can also apply digital transformation to a product using digital technologies such as robot automation during the product development process [49]. Due to the availability 
of digital technology resources now, Kotarba [83] has suggested that organizations need to increase their awareness of changes to the existing value of products.

Digital technologies allow organizations to collaborate to develop new innovative products or services aligned with customer demand [39]. The Internet and social media allow customers to help others by sharing product user experiences and product reviews. Digital technologies allow customers to co-create value by giving suggestions for product improvement, influencing product development, and participating in customizing products or services $[63,84,85]$.

\subsubsection{Processes}

Processes refer to how a firm carries out their tasks [18]; they are a series of activities that a firm must do to achieve a specific result. Advanced digital technology provides firms with a chance to improve their business processes in several ways [63]. For instance, Global Positioning System (GPS) technology can help courier service companies track delivery movements; smartphones and the Internet enable employees to work anywhere and anytime; smart manufacturing technology offers automatic processes, higher quality products, and greater efficiency. Therefore, an organization can become more responsive to changing customer demand, adapting to fast-changing market developments [63]. Improving operational processes is a critical transformational opportunity [51].

Digital technologies transform processes in an organization and make operations more efficient by improving business processes and applying automation [86]. By applying digital transformation, organizations gain benefits like cost savings, better decision-making processes [87], and faster responses to market change and customer demand, using artificial technology and algorithmic decision-making [88].

Moreover, an evolutionary process enables organizations to create new business models, improve operational processes, and give better customer experiences to create value [52]. Nwankpa and Roumani [80] found that firms with superior technology capability should redesign and rethink existing business processes while adopting digital transformation.

\subsubsection{Customers}

The digital economy has changed customer behavior, values, and needs, indirectly forcing organizations to adapt and improve their strategies to keep customer loyalty. An organization must respond to customers' present demands and expectations and be proactive to address customers' future needs even before customers realize them. By applying this concept to their strategy, an organization can gain a competitive advantage in the digital era [89]. Therefore, digital transformation is frequently initiated by the company's need to understand customers better and improve its service level [63].

Since meeting customers' demands is crucial for organizations to make a profit, having customers focused on digital transformation can have an effect [54]. Through digital transformation, small organizations improve customers' experiences with their products and services [90]. By adopting digital technologies, organizations can deliver better products and services, improve communication with customers, and personalize products/services and customers' experiences [54,63,91].

Nowadays, there are many digital tools that a company can use to know their customers better. Using a customer relationship management (CRM) system, an organization can identify which products customers previously purchased. By applying software analysis tools, organizations can identify which products/services they should offer to a specific customer as complementary products/services [63]. Using data retrieved from a smart system connected to products allows an organization to conduct more refined customer segmentation, alter product/service offerings, and improve pricing strategies [92]. Additionally, social media has altered the way people interact with each other and enabled organizations to engage with customers and attract new customers from around the world [14]. Social media can provide effective communication channels that drive customer engagement with products and services, enhancing business performance [93]. 
There are many interaction channels available, such as mobile, marketplace, and social media, and customers expect organizations to provide products and services across all available channels [93]. If firms do so, customers can get information about products and services and place orders using the most convenient channel for them. Digital technologies also create innovative business models that allow companies to collaborate with their customers to work together on product development, such as co-creation and co-production. Organizations can use social media to find consumer preferences for potential buying habits. Using this scenario, customers can be involved in and influence product development, benefiting customers by meeting their needs and demands better, and providing competitive advantages to the organization [63].

\subsection{Digital Transformation and Sustainability}

Digital transformation also has a significant role in improving business sustainability. Digital technologies bring opportunities to disrupt industries and change the landscape of business competition. By adopting digital technologies, new entrants introduce new business models and create value propositions [94]. Habtay and Holmén [95] suggested that business incumbents must be market-oriented, increase leverage of core capabilities, and integrate disruptive innovation within the established organizational structure, which correlates with better performance. The combination of organizational change and adoption of digital technologies gives organizations the opportunity to increase performance in many areas, such as improved efficiency and reduced costs, increased revenue, more effective knowledge collection, faster and more successful innovation, enhanced customer engagement and customer service, sharing and use, and lastly, the ability to survive digital disruption of the industry [18]. Digital transformation will increase the business sustainability of small service business.

The Covid-19 pandemic has drastically altered the way humans live. The pandemic forced people to work from home, study at home, hold online meetings, and more. These new habits have influenced consumers and consumption culture [96]. Therefore, organizations must be aware of the coronavirus outbreak's economic impact on society and businesses, especially small businesses [96-100]. Many businesses experienced decreasing revenue, had to lay off employees, and even closed altogether. Organizations were forced to transform their business transactions through digital technologies in order to survive. Due to changing consumer behavior towards online transactions as an impact of the pandemic, the number of online transactions has risen rapidly [16]. In a time of crisis, digital technologies provide small businesses with a chance for higher business sustainability.

\section{Research Methodology}

\subsection{Methods}

This study collected empirical data from multiple cases to explore and examine the topic more comprehensively. A case study is an examination method of an actual case by collecting data from various information sources [101]. Scholars consider the case study method less meaningful in terms of generalizations concerning the results. Therefore, scholars do not apply the case study approach for theory-building and hypothesis-testing [102]. However, multiple case studies have been considered a proper approach to build a theory regarding its replication and extension [103]. Although multiple case studies provide more reliable and more robust evidence than single case studies, the multiple case study method is more expensive and requires more time. Therefore, in applying the method, researchers must restrict the number of cases.

Researchers use the multiple cases method for flexibility in exploring theoretical evolutions and broader research questions [103]. In this study, we favored multiple exploratory cases rather than examining a single case to understand the correlation and variances among the selected cases, and explain the study's significance. The multiple case study method is superior to explore deeper and broader research questions and theoretical developments, and suits 'how' and 'why' research questions. Therefore, scholars consider 
multiple case study methods suitable for deriving theories, and for giving recommendations that are grounded in extensive empirical evidence [103].

\subsection{Subjects}

In this study, the organizations observed were selected by applying a combination of judgment-sampling and quota sampling from a list of small service business of the SME administration. The selected subjects had to be conveniently located or able provide the required information [104]. The judgment-sampling method is cheap, convenient, timeefficient, and an ideal method for an exploratory study; however, the method has limitations in terms of its subjectivity and generalizability [105]. To gather information from different characteristic industries, the selected subjects came from various service industries-in this case, from wholesale trade and retail. Table 2 shows the basic information of the participating organization. These firms were from different service sectors and located in three different cities.

Table 2. Basic information of the selected cases.

\begin{tabular}{ccccc}
\hline No. & Company ID & Location & Products/Services & Job Title \\
\hline 1 & A & Taipei & Food and Beverage & General Manager \\
\hline 2 & B & New Taipei & Bed and Breakfast (homestay) & Chairman \\
\hline 3 & C & Taipei & Backpacker hostels & Manager \\
\hline 4 & D & New Taipei & Foods and Drinks & Founder \\
\hline 5 & E & New Taipei & Vegetarian Restaurant & Head of Chef \\
\hline 6 & F & Kaohsiung & $\begin{array}{c}\text { Natural care and } \\
\text { Aromatherapy }\end{array}$ & General Manager \\
\hline 7 & G & Taipei & Supermarket (retail) & Special Assistant \\
\hline 8 & H & Taipei & Dishwasher & General Manager \\
\hline 9 & I & New Taipei & Toys store & General Manager \\
\hline 10 & J & Taipei & Café and Tea House & Director \\
\hline
\end{tabular}

This study was conducted by interviewing the top management of organizations with close engagement with management and operations, such as Owner/Founder, Chairman, Director, General Manager, Manager, Head Chef, and Special Assistant. Interviews were conducted at the subjects' site, and lasted between 60 and $120 \mathrm{~min}$.

\subsection{Data Collection and Analysis}

This study obtained data through an interview for every case. The three widely used interview methods are unstructured, semi-structured, and structured interviews [106]. This study used semi-structured interviews with formalized questions. Instead of strictly following the questions, the interviewer used open-ended questions and allowed for discussion to embrace a broader and more in-depth understanding of the topic. The method was chosen to give the subject freedom to reveal their opinion on their terms and give a better understanding to the researcher.

The study gathered the research data by interviewing selected cases. The outlined interview was developed by referring to the research framework. The research instruments were validated by a panel of experts [104], including one professional and three academics. By interviewing top management, the study explored digital transformation in small service business in the context of the demand of DT applications, barriers, and government roles.

This study used semi-structured interviews. Before the interview, we contacted the top management first by email or phone to obtain consent. Then, the interview outline was sent. The interview was conducted based on the question outline and was led by the respondent's answers; in-depth discussions were allowed to clarify the company's current operating 
situation regarding digital transformation, barriers, difficulties, development issues, and the policy resources and programs required. The advantage of this type of interview is increased flexibility. When entering the interviews, the process was started following the order of the interview outline. According to the actual needs of the interview, the questions were adjusted or supplemented. Then, we applied content analysis to the interview transcripts regarding the current demand for digital transformation applications/tools, barriers to digital transformation, and the need for support, programs, and policies from the government.

The interviews were conducted using an outline but were not limited to the following:

1. Do you have business problems that your organization encounters in terms of strategic or daily operation?

2. What digital technologies/tools does your organization implement to support its business strategies and operations? Why?

3. What digital technologies/tools does your organization need to support its business strategies and operations? Why?

4. What are the impacts of digital technologies implementation on your customers, products, processes, systems, and organization? How?

5. What are the barriers that prevent you from implementing those digital technologies in your business?

6. What do you think of the difficulties regarding digital transformation in your business?

7. Do you have sufficient resources to adopt digital transformation in your organization?

8. As top management, do you have sufficient digital capabilities and knowledge to lead your organization to adopt digital transformation?

9. Does your organization have technical problems preventing implementation of digital technologies/tools? What are they?

10. In your opinion, what should the government do to help small businesses with digital transformation processes?

11. What should the government do to drive digital technologies adoption in your organization and your industry?

12. Do you have specific policies and programs you expect from the government to support your organization or industry?

13. Do you encounter difficulties in participating in government programs? What do you suggest the government should do to eliminate the difficulties?

We analyzed data for each case individually and came to conclusions based on the findings regarding the study objectives. The study used the Cognizant's Digital Transformation Framework [63] to analyze digital transformation implementations in selected cases, and evaluate the demand for DT applications, barriers, and government roles. The study generated a model of barriers and government support for digital transformation in small service business by referring to the data analysis.

\section{Findings and Discussion}

This study conducted interviews to reveal the current state and demand for digital transformation applications and digital transformation barriers in small service business. The interviews also exposed the role of the government in supporting digital transformation in small service business. Table 3 presents the summary data of the interviews. 
Table 3. Interview data regarding digital transformation in small service business.

ID Current and Demand for DT Applications Government's Support and Policies

- Start using automation equipment to replace labor.

- The firm uses Point of Sales (POS) machine with features invoicing, inventory, and other information systems.

- Need digital tools for practical application of learning channels and information.
- Free WiFi available for customers
- Uses an information system for B\&Bs.
- Lack of network collaboration with tourism agencies.

- Homestay's websites are not using a multilingual system, which will be a problem for foreign tourists.

- Many websites for reservation systems have no integration with a payment system.
- Provide talent matching by promoting collaboration between organizations and internship courses outside colleges/universities.

- $\quad$ Set up an agency or platform to help match

- The high price of automation equipment or digital tools

foreigners' talent and business owners in Taiwan to
- Provide training and digital courses.

- Lack of digitally enabled supply chain increase foreigners' employment rates.

- Provide financing loans for working capital with a simple process that is quickly approved.

- $\quad$ Promote digital equipment.

- Assist multilingual traffic signs and optimization of tourism environment and establish a dense bus route connecting the sightseeing spots.

- $\quad$ Assist the website upgrade of the county and city homestay associations, and counsel the practitioners to multilingualism.

- Assist connection between website and payment system.

- Assist in the adjustment of public safety declaration regulations

- $\quad$ Provide repair and upgrade loans for hotel owners
- The firm uses a reservation platform with customer analysis data, price statistics changes, and market observations.

C

- Firms use customer data to analyze customers' profiles, such as country, gender, age, nationality, etc.

- Free WiFi available for customers
- Firms have a lack of workforce.

- Have limited funds for executing innovative ideas.
- Documents to apply government project plans are complicated, and the process is too long. The company has not enough human resources to do it. The application of the government project plan should be simplified and electronic.

- The government can provide some small subsidies to support enterprises to implement new innovative ideas. 
Table 3. Cont.

ID Current and Demand for DT Applications

\section{Government's Support and Policies}

- The government should actively promote to make mobile payment more popular.

- $\quad$ Free WiFi available for customers

- Demand to apply logistic management system.

- Expecting mobile payment should be more popular.

- Have a plan to use a digital menu.
- Lack of knowledge regarding catering equipment and technology.

- $\quad$ The cost of adopting automatic machines/cooking equipment is too high.
- The government should promote digital tools and future digital trends.

- Expecting the government to provide a subsidy to support companies that start using digital technologies until they can rely on their ability.

- The government can adjust the time for the review of fire regulations and speed up the process.
- $\quad$ Using Facebook and LINE@ as marketing promotion tools.

E

- Use iChef's POS machines

- Demand for a management system and inventory system.

- $\quad$ Using the Internet (e-commerce) as a sales channel.

- Use live broadcast sales. sharing knowledge among employees.

- Introduce a chat robot to provide 24-hours

- $\quad$ Lack of digital marketing capabilities
- Using computers and video for training and
- Lack of technological capabilities

- Lack of funding for business development.
- $\quad$ Need government loan subsidies to assist business development

- Aromatherapy regulations are limited. The firm is looking forward to a chance for discussion.

- In addition to government resource assistance, companies still need to strengthen their digital capabilities.

- Complicated paperwork to apply to the government's program. The government should provide more assistance regarding business and less about regulation and policies.

- Early working capital assistance is required because of the delay time of cash flow 
Table 3. Cont.

ID Current and Demand for DT Applications

G $\quad-\quad$ The company uses a logistic distribution system.

- No digital application

- The cost of digital marketing is high because it needs

- Number one of toy model store on the Internet.

- Do online auction

I - Have a website as a selling channel.

- Using social media for advertising.

- Require stock management for sales data

- Planning of using their suitable advertising tools

- Using several accounts in social media for several different brands.

- Through the Service Industry Innovation Research (SIIR) program from the Ministry of

J Economic Affairs, the organization develops an integrated system (e-commerce, mobile, multimedia, manufacturer app, etc.).

- Need to build a database for an online store, vendor, and customer.

\section{Barriers of DT}

- The owner has a low capability of the digital environment.

- The owner has a lack of ability in information engineering and maintenance.

- The owner has a lack of capability to operate an e-commerce platform.

- Small stores have insufficient resources and are unfamiliar with operating e-commerce platforms.

- Lack of technology capabilities more people to handle it.

\section{Government's Support and Policies}

- The government should establish a multi-functional integrated platform for looking for channels, agents, legal affairs, education, training, etc.

- The government should introduce e-commerce platforms; therefore, the organization could start using a B2C platform.

- The government can purchase new startup products to help its growth

- $\quad$ The government should hold pre-training seminars on business or entrepreneurship to reduce the probability of business failure.

- The government should provide possible factors for the operation's failure for the industry's reference and provide relevant assistance.

- Lack of human resources to manage social media account

- Many payment platforms are available but have no integration.

- Collaboration with electronic cards (e.g., Yoyo Card) needs a lot of funds for a deposit.
- A district government should hold more programs to introduce more digital tools.

- The government should provide incentives and an environment for innovation.

- $\quad$ Building a platform to connect small businesses with internet content provider services (e.g., social media). 
The study revealed that small businesses experience digital transformation at various levels, from no digital system to applying advanced technologies. Organizations have different digital technology adoption levels due to their various digital capabilities, resources, market targets, and business needs. From the perspective of the market target, small service business targeting foreign tourists have a greater intention to adopt DT applications compared to small businesses that target local customers. Otherwise, a small service business that wants to be a market leader in the industry and have digital capabilities will be digitalized better than a small business with limited resources and a lack of digital capabilities.

This study classified DT applications into the digital transformation dimension, objectives, and benefits, as shown in Table 4 . The majority of digital transformation applications are related to customers and processes/systems; only Free WiFi services are related to the product dimension, and no applications exist regarding the organization dimension. The study found there are no digitalized products/services among small service business. By analyzing the products/services' characteristics, we can conclude that the studied products/services are impossible to digitalize. However, there are chances for several small businesses (case B and C) to embed their services with digital technology features. Embedding digital services is also provided by international restaurants and cafes, such as Starbucks [82] and McDonalds.

Table 4. Dimensions, applications, objectives, and benefits of DT in small service business.

\begin{tabular}{|c|c|c|c|}
\hline No. & Dimension & DT Applications & Objectives and Benefit \\
\hline $\mathrm{I}$ & Organizational & - & - \\
\hline \multirow{9}{*}{ II } & \multirow{9}{*}{ Process and System } & Automation tools to replace labor & Increase cost efficiency \\
\hline & & Using POS & Increase cost efficiency \\
\hline & & Demand for a digital learning platform & Increase efficiency, increase employee skill \\
\hline & & Information system of B\&B & Increase efficiency, agile approach to work \\
\hline & & $\begin{array}{l}\text { Reservation online platform and } \\
\text { customer data analysis }\end{array}$ & customer experience and customer insight \\
\hline & & Using tools for customers' data analysis & customer insight \\
\hline & & Demand for apply logistic system & an agile approach to work \\
\hline & & Inventory management system & an agile approach to work \\
\hline & & $\begin{array}{c}\text { Integrate e-commerce, mobile, } \\
\text { multimedia, and manufacturer app into } \\
\text { one system. }\end{array}$ & $\begin{array}{l}\text { an agile approach to work, using digital } \\
\text { marketing, enhance customers' experience }\end{array}$ \\
\hline \multirow{8}{*}{ III } & \multirow{8}{*}{ Customers } & $\begin{array}{l}\text { Social media account and social } \\
\text { media advertising }\end{array}$ & $\begin{array}{l}\text { engagement with customers, insight } \\
\text { customer preferences }\end{array}$ \\
\hline & & Online auction & increase sales and customers experience \\
\hline & & Live broadcast sales & $\begin{array}{l}\text { engagement with customers, increase sales and } \\
\text { customers experience }\end{array}$ \\
\hline & & Chat robot & $\begin{array}{l}\text { engagement with customers, increase } \\
\text { customers experience }\end{array}$ \\
\hline & & Demand for using digital menu & customers experience \\
\hline & & e-commerce for sales channel & increase sales and customers experience \\
\hline & & Have a website for selling & $\begin{array}{l}\text { engagement with customers, increase sales and } \\
\text { customers experience }\end{array}$ \\
\hline & & Database for customers and vendors & insight customers \\
\hline IV & Products & Free $\mathrm{WiFi}$ & customers experience \\
\hline
\end{tabular}


Various applications related to processes and systems show that small service business are struggling with increasing operation costs. Market competition forces small service business to increase their business efficiency to stay competitive. Small service business have also adopted various DT applications for agile approaches to working due to the dynamic nature of the market and advanced digital technologies. Small businesses need to work with sufficient customer insight to utilize the right business strategies.

This study found there are no applications in the organization dimension. This finding suggests that small service business lack networking capabilities. Small service business can have difficulties building collaboration with other parties that will allow them to share resources and knowledge. This finding also reveals that the dynamic partner ecosystem among small businesses in Taiwan is not mature. Furthermore, it shows that small service business lack digital skills, and have no virtual workplace.

Digital transformation can affect many business areas within an organization and many stakeholders, such as within product development, marketing, human resources, IT, management, and strategy [74]. Previous studies suggest most manufacturers adopt digital transformation to improve processes and increase productivity [21], customize products [92], increase efficiency in production processes [8], or exchange customer data for servitization [107]. This study found that small service business mostly apply digital transformation to enhance the customer experience, apply agile approaches to work, and increase engagement and collaboration with customers. By applying digital transformation applications, small service business can expect to improve business performance, achieve business growth, and obtain a competitive advantage by increasing customer engagement. This finding implies that a firm should choose their priority area wisely when applying digital transformation to gain the maximum benefits, especially when firms have limited resources to apply digital transformation across all business functions. This finding also aligns with the previous study's suggestion [108] that firms must select priority areas during digital transformation activities. Therefore, this study proposes that the industry's characteristics and nature should be a dimension of thinking when considering a priority digital transformation area.

Due to a lack of funding and resources, cost is one of the main barriers for small service business to adopt digital technologies. This finding is not surprising, given that small businesses have limited resources and cash flow. If an organization struggles to fund daily operations, investment in technology adoption will be not a priority. Moreover, digital technologies adoption requires significant investment without a guarantee of success. This could be why the digitalization level of SME services is low [14]. This finding is in line with most previous digital transformation literature in suggesting the cost of implementation is a primary barrier to digital technologies adoption by small businesses [21]. Since a lack of funding can cause other barriers, small service business are challenged to deal first with these barriers.

Another barrier to digital transformation adoption in small service business is the lack of digital capability (e.g., digital marketing, digital skill). A lack of digital capabilities could be caused by limited capital resources. Lack of funding restricts small businesses from adopting new technologies and prevents top management and employees from updating their skills. Small businesses have operated for years with basic technologies, and limited updating of digital technologies knowledge among owners or managers. Therefore, owners/managers who have limited digital technology understanding have advanced rapidly, and this can significantly impact their business. Having a lack of digital capability and insufficient capital resources drives owners/managers to prefer to invest or innovate in other ways; in something they know, and which is inexpensive, instead of investing in digital transformation. Unless small businesses acquire technology knowledge through training, participating in government programs, or collaborating with other parties, and are supported by adequate funding, their technology capabilities will remain the same or worsen. Small business owners/managers will still lack knowledge around selling products online using e-commerce channels, live broadcasts, social media, websites, and other digital applications. 
Small businesses also have a lack of human resources as a barrier to adopting digital technologies. It is easy for large firms to attract technology-skilled talent because they have adequate remuneration and career paths. Large firms can hire talent from overseas. Small businesses have limited capital resources and networks that prevent them from investing in foreign workers. Moreover, the lack of funding restricts small businesses from expanding their business to challenge and provide career paths to their employees. Therefore, a small business can encounter difficulties in hiring employees suited for digital transformation adoption. Small service business expect the government to provide a digital platform and programs to help small businesses find qualified talent and train their employees.

Small service business experience technical and technological barriers (e.g., payment integration inter-platforms) during digital transformation. There are many digital tools available, but they lack integration. After adopting a digital platform, small businesses will have difficulties adopting another technology, because there is no interconnection between them.

This study found at least four government roles to assist small service business in terms of digital transformation. First, due to a lack of funding and insufficient digital capability, a small service business cannot build its digital platform. Further, due to being less profitable economically, a digital platform from a third party may be unavailable. Therefore, the government can help small businesses build a digital platform for digital transformation in small service business. By using this platform, small service business could digitalize their business internally, as well as externally. The government could also promote digital tools to help small service business transform their businesses. There are many digital tools available, such as e-commerce, official websites, social media, mobile applications, and more. Different digital tools will be suitable for specific products/services and specific purposes. Therefore, a small business needs to find one or two digital tools suitable for its business usage.

Secondly, to enhance digital transformation, the government must promote mobile/digital payment. Digital payment systems have an important role in digital business ecosystems, but require a minimum number of merchants and a minimum number of customers. When a digital payment system is issued by a big company (e.g., Alibaba with Alipay), they have sufficient resources and economic power to drive users to use the digital payment system until the payment system achieves economic scale. Small service business have insufficient resources and economic power to create and build a business ecosystem for a digital payment system. Therefore, small service business require the government to create a mobile/digital payment system, develop the business ecosystem, and promote its usage.

Moreover, small businesses need the government to facilitate connections between websites and payment systems. Integrated e-commerce and payment systems will provide convenience to customers, enhancing transaction intention. Small businesses also require the government to promote safety regulations, establish digital transaction regulations, and enforce digital payment security standards and certification. The government must conduct security certification to ensure the safety of the payment system. Security of transactions and safety regulations will increase customers' trust, thereby increasing the number of transactions.

Third, the government can help small service business increase their digital capability by giving digital training or education to owners or managers. Digital training can increase the digital knowledge of small business owners/managers and affect an organization's digital capability. Increasing the digital capability of small business owners/managers is crucial for digital transformation success in small service business. Sufficient knowledge of digital technologies will drive owners/managers to develop a digital vision. In addition, digital capability is an important driving factor for digital innovation that will influence an organization's digital skill in developing new digital products to meet new customers' needs [109]. Moreover, the government can help small businesses develop a digital learning and training system to train their employees. This system could help a small business to decrease the cost of new employee hiring and training. 
Fourth, the government can support small businesses by building a collaborative ecosystem that helps small businesses build their network and collaborate with other parties. Collaboration systems will help small businesses to build a network with other parties and create collaborative innovation. By participating in collaboration, small service business can overcome limited resources, a lack of human resources, and a lack of knowledge. There are four collaboration models that small service business can use, as follows: knowledgesharing, resource-sharing, marketing innovation, and product/service innovation models. By establishing collaboration with partners, a small business can increase business performance and achieve business growth, even though they have limited resources [39].

This study constructed a model for drivers, barriers, and government support of digital transformation in small service business, as shown in Figure 1. The model explains the relationship between drivers, barriers, and government roles in digital transformation in small service business graphically. Most of the existing frameworks from previous studies were built assuming an organization has sufficient resources and digital capabilities to implement digital transformation. This study built a model for small service business with limited resources and lacking in digital capabilities, and reveals how the government should help them adopt digital technologies. This study proposed that the government's role is an indispensable component of the digital transformation framework in small service business.

Finally, the study found that the government's role contributes significantly to digital transformation in small service business. It is hard for small service business to deal with barriers using only their own resources and capabilities. Government support will provide small businesses with the resources and power to overcome the barriers of digital transformation. Having support from the government will give small service business opportunities in digital transformation and help them achieve their business objectives. From the perspective of sustainability, the adoption of digital technologies will increase business performance and business growth of small service business and give small businesses a chance of survival during a crisis, such as Covid-19. Government support enhances the business sustainability of small service business, impacting the nation's economic sustainability. 


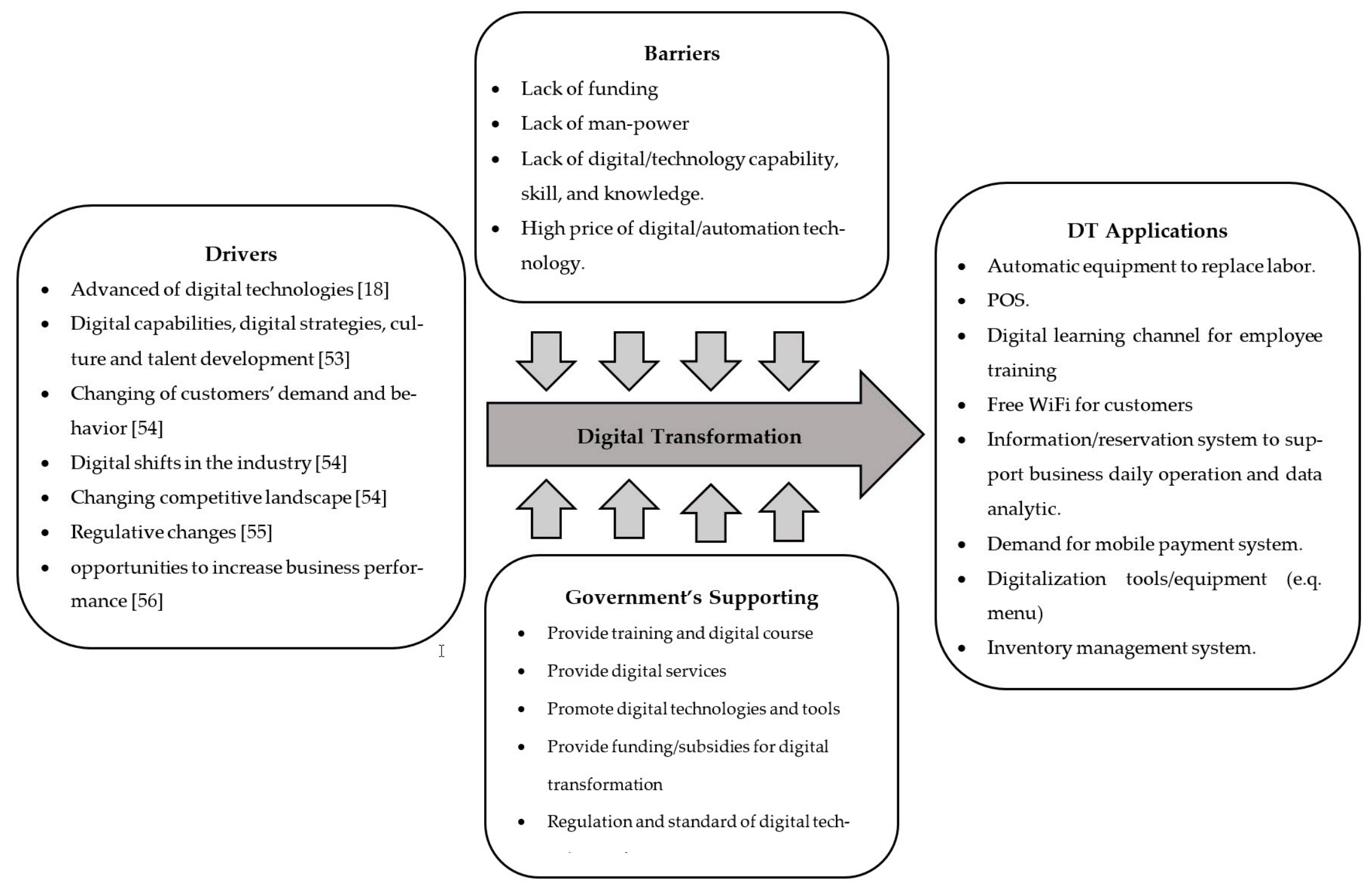

Figure 1. Model for drivers, barriers, and government's support to digital transformation in small service business. 


\section{Conclusions}

The paper contributes to theoretical and managerial implications by examining numerous digital transformation aspects in small service business. This study found that small service business mostly apply digital transformation to enhance the customer experience, increase engagement, and collaborate with customers. There are significant differences in the objectives of digital transformation between small business manufacturers and services. Therefore, this study proposes that the industry's characteristics and nature are determinants of the digital transformation priority area. This study found that small service business have an exceptionally high demand for digital transformation to increase their business performance, productivity, and business growth. From a technology diffusion perspective, funding and resources are the main barriers to digital transformation in small service business. Small businesses require the government to provide funding programs to solve funding and resource problems. The government is also suggested to create a digital learning platform to enhance small service business' digital capabilities. Moreover, small businesses must deal with human resource and technical problems to achieve digital transformation success.

Based on a thorough analysis of interview data, this study explored the government's role in supporting digital transformation in small service business. The government needs to provide funding programs to finance digital transformation, create a digital learning platform for small businesses, and promote digital tools. Small service business expect the government to promote digital payment, ensure its safety, and increase integration with other digital platforms to enhance digital payment usage. The government can also support digital transformation in small businesses by building a digital platform for small businesses for collaboration and networking. The government can use this finding to determine roles, policies, and programs to support digital transformation in small service business. This suggestion is also consistent with the government's policy to support small businesses in enhancing their business growth, which will impact the nation's economic growth and sustainability.

\subsection{Managerial Implications}

This research has several managerial implications. Small business owners/managers must realize that digital technologies have disruptive business competition potential, and this can drive organizations to adopt digital transformation. Since one of the main barriers to this is a lack of digital capabilities, this study suggests that owners/managers increase their digital knowledge and skill. Having technological knowledge and skills will increase managers/owner's awareness of market competition changes and increase their ability to develop clear digital transformation objectives. Digital transformation success implies increasing the organization's competitive advantage, enhancing business performance, improving productivity, and achieving business growth.

This study suggests that small business owners/managers could collaborate with educational institutions and create job training programs to solve human capital problems. A student with sufficient digital technology knowledge could help small shop owners communicate and interact with digital platform operators, and even contribute to the design of products/services. Such a program could help students interact with business owners/managers, learn how to manage a small business, and be hired directly by a small business after graduation, thus benefiting both parties.

In some countries the government provides many policies and programs to support small businesses. This study suggests small businesses should be more independent as the business experiences growth. To solve financial problems, small service business should learn how to build a good financial record to gain financial access to banking. Financial records will help small businesses to apply for funding from banks and investors. To solve the problem of a lack of digital capabilities, small service business are suggested to enhance their digital knowledge and capabilities by using the internet as a knowledge resource. 
For small service businesses that have a business dependency on other sectors in an industry (e.g., tourism), creating business collaboration through an association or business communities is recommended. Small businesses can exchange information and knowledge, create services together, and deal with business problems. Through this collaboration, small businesses can enhance their business independence from the government.

Mindfull of the role of small businesses in the national economy, the Taiwan government allocates a budget annually through the Small and Medium Enterprise Administration, Ministry of Economic Affairs (SMEA, MOEA), to support small businesses. The government creates many programs to support SMEs, providing counseling programs, improvements of the legal system, participation in international exchanges, talent cultivation for SMEs, procurement from SMEs, the organization of various selection and commendation activities for SMEs, and funding through grants and subsidized loans [30]. To support digital transformation in SMEs, Taiwan's government has several programs: the digital outreach program, Mobile Payment Popularization, Promotion and Cloud Innovative Application Development Plan, and Digital Broadband Applications Popularization and Promotion Plan [30]. The study's findings imply that the government should add to and alter their program by including the following: creating a digital platform for small businesses, developing the digital learning platform, promoting digital payment systems, and funding digital transformation in small service business. There is a gap between the study's findings and government programs. Altering and improving the government's programs will support small businesses in their digital transformation processes, and help small businesses improve their business performance, gain competitive advantages, improve productivity, and achieve business growth.

\subsection{Limitations and Future Research}

This study is based on multi-case research of small service business in Taiwan. Further research might be conducted on other organizations in other countries. The results might differ due to the level of technology acceptance, business competition, society, and government involvement in supporting small businesses.

This study reveals barriers to digital technology adoption, and the government's roles in supporting digital transformation in small service business. Nevertheless, employing qualitative research methods restricts the study to determining which barriers and governmental roles are the most impactful for the success or failure of digital transformation in small businesses. Therefore, this study suggests that future research should integrate a quantitative method to examine the barriers and governmental roles that can substantially influence small service business' digital transformation.

Author Contributions: Conceptualization C.-L.C., Y.-C.L., W.-H.C. and C.-F.C.; Data curation C.L.C., Y.-C.L., and C.-F.C.; Methodology C.-L.C., Y.-C.L., W.-H.C., and H.P.; Project administration C.-L.C., Y.-C.L., and C.-F.C.; Resources C.-L.C., Y.-C.L., W.-H.C. and C.-F.C.; Validation C.-L.C., Y.-C.L., W.-H.C., C.-F.C., and H.P.; Writing review and editing C.-L.C., Y.-C.L., W.-H.C., and H.P.; Writingoriginal draft W.-H.C. and H.P.; Funding acquisition, Investigation and Supervision C.-F.C.; and Formal analysis H.P. All authors have read and agreed to the published version of the manuscript.

Funding: This research received no external funding.

Institutional Review Board Statement: Not applicable.

Informed Consent Statement: Participants gave their consent before interview and agreed to publish data anonymously.

Data Availability Statement: The data presented in this study are available on request from the corresponding author. The data are not publicly available due to participants consent and privacy.

Acknowledgments: The authors thank all case organizations and interviewees and the three anonymous reviewers for their valuable contributions to the article. The authors gratefully acknowledged the Small and Medium Enterprise Administration, Ministry of Economic Affairs of Taiwan for this research. 
Conflicts of Interest: The authors declare no conflict of interest.

\section{References}

1. Sundaram, R.; Sharma, R.; Shakya, A. Digital transformation of business models: A systematic review of impact on revenue and supply chain. Int. J. Manag. 2020, 11, 9-21. [CrossRef]

2. Eller, R.; Alford, P.; Kallmünzer, A.; Peters, M. Antecedents, consequences, and challenges of small and medium-sized enterprise digitalisation. J. Bus. Res. 2020, 112, 119-127. [CrossRef]

3. Khanchel, H. The Impact of Digital Transformation on Banking. J. Bus. Adm. Res. 2019, 8, 20. [CrossRef]

4. Ying-Yu, K.C.; Yi-Long, J.; Yu-Hsien, W. Effect of Digital Transformation on Organisational Performance of SMEs: Evidence from the Taiwanese Textile Industry's Web Portal. Internet Res. 2016, 26, 186-212. [CrossRef]

5. Mubarak, M.F.; Shaikh, F.A.; Mubarik, M.; Samo, K.A.; Mastoi, S. The Impact of Digital Transformation on Business PerformanceA Study of Pakistani SMEs. Eng. Technol. Appl. Sci. Res. 2019, 9, 5050-5061. [CrossRef]

6. $\quad$ Downes, L.; Nunes, P.F. Big-bang disruption. Harv. Bus. Rev. 2013, 91, 44-56.

7. Curraj, E. Business Digitalisation of SMEs in Albania: Innovative Approaches and Their Impact on Performance. Ph.D. Thesis, European University of Tirana, Tirana, Albania, 2018.

8. Gigova, T.; Valeva, K.; Nikolova-Alexieva, V. Digital Transformation-Opportunity for Industrial Growth. In Proceedings of the 2019 International Conference on Creative Business for Smart and Sustainable Growth (CREBUS), Sandanski, Bulgari, 18-21 March 2019; pp. 1-4. [CrossRef]

9. Liu, D.Y.; Chen, S.W.; Chou, T.C. Resource fit in digital transformation: Lessons learned from the CBC Bank global e-banking project. Manag. Decis. 2011, 49, 1728-1742. [CrossRef]

10. Chen, Y. Improving market performance in the digital economy. China Econ. Rev. 2020, 62. [CrossRef]

11. Nambisan, S.; Wright, M.; Feldman, M. The digital transformation of innovation and entrepreneurship: Progress challenges and key themes. Res. Policy 2019, 48, 1-9. [CrossRef]

12. Monllor, J.; Soto-Simeone, A. The impact that exposure to digital fabrication technology has on student entrepreneurial intentions. Int. J. Entrep. Behav. Res. 2019, 26, 1505-1523. [CrossRef]

13. Reuschke, D.; Mason, C. The engagement of home-based businesses in the digital economy. Futures 2020. [CrossRef]

14. Chang, A.; Kuentz, J.F.; Wiseman, B.; Seong, J.; Lan, J.; Tan, C.; Chang, J.; Chen, E.; Tang, D. Taiwan's Digital Imperative: How a Digital Transformation Can Re-Ignite Economic Growth. 2017. Available online: http://mckinseychina.com/wp-content/ uploads/2017/10/McKinsey_Taiwans-Digital-Imperative-EN.pdf (accessed on 20 July 2020).

15. Li, W.; Liu, K.; Belitski, M.; Ghobadian, A.; O’Regan, N. e-Leadership through strategic alignment: An empirical study of smalland medium-sized enterprises in the digital age. J. Inf. Technol. 2016, 31, 185-206. [CrossRef]

16. Junusi, R.E. Digital Marketing during the Pandemic Period: A Study of Islamic Perspective. J. Digit. Mark. Halal Ind. 2020, 2, 15. Available online: https://journal.walisongo.ac.id/index.php/JDMHI/article/view/5717 (accessed on 5 November 2020). [CrossRef]

17. Sirilli, G.; Evangelista, R. Technological innovation in services and manufacturing: Results from Italian surveys. Res. Policy 1998, 27, 881-899. [CrossRef]

18. Wade, M. Digital Business Transformation: A Conceptual Framework. Global Center for Digital Business Transformation. 2015. Available online: https://www.imd.org/globalassets/dbt/docs/framework (accessed on 22 October 2020).

19. UEAPME. Best Practices on Assisting SMEs with the Digital Transformation. February 2018. Available online: http://apcal.lu/wpcontent/uploads /2018/04/2018-03-22-BIPAR-Best_practices_on_assisting_SMEs_with_the_digital_transformation.pdf (accessed on 20 August 2020).

20. Hausberg, J.P.; Liere-Netheler, K.; Packmohr, S.; Pakura, S.; Vogelsang, K. Research streams on digital transformation from a holistic business perspective: A systematic literature review and citation network analysis. J. Bus. Econ. 2019, 89, 931-963. [CrossRef]

21. Ghobakhloo, M.; Ching, N.T. Adoption of digital technologies of smart manufacturing in SMEs. J. Ind. Inf. Integr. $2019,16$. [CrossRef]

22. Kutzner, K.; Schoormann, T.; Knackstedt, R. Digital Transformation in Information Systems Research: A Taxonomy-Based Approach to Structure the Field. Res. Pap. 2018, 56. Available online: https://aisel.aisnet.org/ecis2018_rp/56 (accessed on 15 July 2020).

23. Ramilo, R.; Embi, M.R.B. Critical analysis of key determinants and barriers to digital innovation adoption among architectural organisations. Front. Archit. Res. 2014, 3, 431-451. [CrossRef]

24. Eloranta, V.; Turunen, T. Seeking competitive advantage with service infusion: A systematic literature review. J. Serv. Manag. 2015, 26, 394-425. [CrossRef]

25. Sepulveda, F.L. Does service intangibility affect entrepreneurial orientation? Serv. Ind. J. 2014, 34, 604-629. [CrossRef]

26. Coluzzi, C.; Ferrando, A.; Martinez-Carrascal, C. Financing obstacles and growth: An analysis for euro area non-financial firms. Eur. J. Financ. 2015, 21, 773-790. [CrossRef]

27. Wang, Y. What are the biggest obstacles to growth of SMEs in developing countries?-An empirical evidence from an enterprise survey. Borsa Istanb. Rev. 2012, 16, 167-176. [CrossRef]

28. OECD/ERIA. SME Policy Index: ASEAN 2018: Boosting Competitiveness and Inclusive Growth; OECD Publishing: Paris, France; Economic Research Institute for ASEAN and East Asia Jakarta: Jakarta, Indonesia, 2018. [CrossRef] 
29. Scheers, L. SMEs' marketing skills challenges in South Africa. Afr. J. Bus. Manag. 2011, 5, 5048-5056.

30. SMEA MOEA. The White Paper of Small and Medium Enterprise 2019. Taipei City Taiwan. 2020. Available online: https: / / www.moeasmea.gov.tw/list-en-2572 (accessed on 18 September 2020).

31. Ayyagari, M.; Demirguc-Kunt, A.; Maksimovic, V. Who creates jobs in developing countries? Small Bus. Econ. 2014, 43, 75-99. [CrossRef]

32. Gomes, G.; Wojahn, R.M. Organizational learning capability innovation and performance: Study in small and medium-sized enterprises (SMES). Rev. Adm. 2017, 52, 163-175. [CrossRef]

33. Muller, P.; Gagliardi, D.; Caliandro, C.; Bohn, N.U.; Klitou, D. Annual Report on European SMEs 2013/2014-A Partial and Fragile Recovery". Final Report-July 2014 European Commission Directorate-General for Enterprise and Industry: Etterbeek Belgium. 2014. Available online: https:/ / op.europa.eu/en/publication-detail/-/publication/2fe47dcb-9ae6-41ab-a037-a3b4d897c5ac (accessed on 21 October 2020).

34. Karadag, H. The Role of SMEs and Entrepreneurship on Economic Growth in Emerging Economies within the Post-Crisis Era: An Analysis from Turkey. J. Small Bus. Entrep. Dev. 2016, 4, 22-31. [CrossRef]

35. Li, L.; Ci, J.; Gao, X. The Growth Evaluation Model of Manufacturing SMEs and Application from System Engineering Perspective. Syst. Eng. Procedia 2012, 5, 412-419. [CrossRef]

36. Eniola, A.; Entebang, H. Government Policy and Performance of Small and Medium Business Management. Int. J.Acad. Res. Bus. Soc. Sci. 2015, 5, 237-248. [CrossRef]

37. Kraja, Y.B.; Osmani, E.; Molla, F. The Role of the Government Policy for Support the SME-s. Acad. J. Interdiscip. Stud. 2014, 3, 391-396. [CrossRef]

38. Li, L.; Su, F.; Zhang, W.; Mao, J. Digital transformation by SME entrepreneurs: A capability perspective. Inf. Syst. J. 2017, 28, 1129-1157. [CrossRef]

39. Lin, Y.; Chen, C.; Chao, C.; Chen, W.; Pandia, H. The Study of Evaluation Index of Growth Evaluation of Science and Technological Innovation Micro-Enterprises. Sustainability 2020, 12, 6233. [CrossRef]

40. Thomas, G.A. Typology for the case study in social science following a review of definition, discourse and structure. Qual. Inq. 2011, 17, 511-521. [CrossRef]

41. Park, S.; Lee, I.H.; Kim, J.E. Government support and small- and medium-sized enterprise (SME) performance: The moderating effects of diagnostic and support services. Asian Bus. Manag. 2020, 19, 213-238. [CrossRef]

42. Pelletier, C.; Cloutier, L.M. Conceptualising digital transformation in SMEs: An ecosystemic perspective. J. Small Bus. Enterp. Dev. 2019, 26, 855-876. [CrossRef]

43. Ettlie, J.; Rosenthal, S. Service versus Manufacturing Innovation. J. Prod. Innov. Manag. 2011, 28, 285-299. [CrossRef]

44. Gremyr, I.; Witell, L.; Löfberg, N.; Edvardsson, B.; Fundin, A. Understanding new service development and service innovation through innovation modes. J. Bus. Ind. Mark. 2014, 29, 123-131. [CrossRef]

45. Kindström, D.; Kowalkowski, C.; Alejandro, T.B. Adding services to product-based portfolios: An exploration of the implications for the sales function. J. Serv. Manag. 2015, 26, 372-393. [CrossRef]

46. Matzner, M.; Büttgen, M.; Demirkan, H.; Spohrer, J.; Alter, S.; Fritzsche, A.; Ng, I.C.L.; Jonas, J.M.; Martinez, V.; Möslein, K.M.; et al. Digital Transformation in Service Management. J. Serv. Manag. Res. 2018, 2, 2-21. [CrossRef]

47. Manyika, J. Digitization AI and Productivity. McKensey Global Institute Research. 2018. Available online: http:/ /www.oecd.org/ sti/ind/digital-transformation-business-session-2-manyika.pdf (accessed on 21 September 2020).

48. McKensey Global Institute. Twenty-Five Years of Digitisation: Ten Insights into How to Play it Right. Digital Enterprise Show 21-23 May 2019 Madrid. Available online: https: / / www.mckinsey.com/ \{\}/media/mckinsey/business\%20functions/ mckinsey \%20digital/our\%20insights/twenty-five \%20years $\% 20$ of $\% 20$ digitization $\% 20$ ten $\% 20$ insights $\% 20$ into $\% 20$ how $\% 20$ to $\%$ 20play\%20it\%20right/mgi-briefing-note-twenty-five-years-of-digitization-may-2019.ashx (accessed on 20 September 2020).

49. Hess, T.; Matt, C.; Benlian, A.; Wiesböck, F. Options for Formulating a Digital Transformation Strategy. MIS Q. Exec. 2016, 15, 103-119.

50. Matt, C.; Hess, T.; Benlian, A. Digital Transformation Strategies. Bus. Inf. Syst. Eng. 2015, 57, 339-343. [CrossRef]

51. Berman, S.J. Digital Transformation: Opportunities to Create New Business Models. Strategy Leadersh. 2012, 40, 16-24. [CrossRef]

52. Morakanyane, R.; Grace, A.; O'Reilly, P. Conceptualizing digital transformation in business organisations: A systematic review of literature. In Proceedings of the 30th Bled EConference: Digital Transformation-From Connecting Things to Transforming Our Lives BLED 2017, Bled, Slovenia, 18-21 June 2017; pp. 427-444. [CrossRef]

53. Kane, G.; Palmer, D.; Phillips, A.N. Is your business ready for a digital future. Mit. Sloan Manag. Rev. 2015, 56, 37-44.

54. Piccinini, E.; Gregory, R.W.; Kolbe, L.M. Changes in the Producer-Consumer Relationship—Towards Digital Transformation. Wirtsch. Proc. 2015, 109. Available online: https:/ /aisel.aisnet.org/wi2015/109 (accessed on 20 August 2020).

55. Berghaus, S.; Back, A. Disentangling the Fuzzy Front End of Digital Transformation: Activities and Approaches. In ICIS 2017 Proceedings; Association for Information Systems: Atlanta, GA, USA, 2017.

56. Ezeokoli, F.O.; Okolie, K.C.; Okoye, P.U.; Belonwu, C.C. Digital Transformation in the Nigeria Construction Industry: The Professionals' View. World J. Comput. Appl. Technol. 2016, 4, 23-30. [CrossRef]

57. Parida, V.; Johansson, J.; Braunerhjelm, P. Barriers to information and communcation technology adoption in small firms. Work. Pap. Swed. Entrep. Forum. 2010, 3. Available online: https://entreprenorskapsforum.se/wp-content/uploads/2013/03/WP_03 .pdf (accessed on 20 August 2020). 
58. GIRI. Barriers to the Adoption of Future Digital Engineering Technology; Get It Right Initiative: London, UK, 2019; pp. 1-52. Available online: https:/ / getitright.uk.com/live/files/reports/8-giri-ucl-barriers-adoption-future-digital-engineering-technology-1-45 2.pdf (accessed on 28 September 2020).

59. Reis, J.; Amorim, M.; Melão, N.; Matos, P. Digital Transformation: A Literature Review and Guidelines for Future Research. In Trends and Advances in Information Systems and Technologies. WorldCIST'18 2018. Advances in Intelligent Systems and Computing; Rocha, Á., Adeli, H., Reis, L.P., Costanzo, S., Eds.; Springer: Cham, Germany, 2018; p. 745. [CrossRef]

60. Korachi, Z.; Bounabat, B. Integrated methodological framework for digital transformation strategy building (IMFDS). Int. J. Adv. Comput. Sci. Appl. 2019, 10, 242-250. [CrossRef]

61. Liere-Netheler, K.; Vogelsang, K.; Packmohr, S.; Hoppe, U.A. Towards a Framework for Digital Transformation Success in Manufacturing. Research Papers. 193. Available online: https:/ /aisel.aisnet.org/ecis2018_rp/193 (accessed on 20 July 2020).

62. Nylen, D.; Holmstrom, J. Digital innovation strategy: A framework for diagnosing and improving digital product and service innovation. Bus. Horiz. 2015, 58, 57-67. [CrossRef]

63. Corver, Q.; Elkhuizen, G. A Framework for Digital Business Transformation. Cognizant 2014, 1-10. Available online: https: / / www.cognizant.com/InsightsWhitepapers/a-framework-for-digital-business-transformation-codex-1048.pdf (accessed on 30 July 2020).

64. IBM Institute for Business Value. Digital Reinvention in Action-What to do and How to Make It Happen; IBM Institute for Business Value: Armonk, NY, USA, 2013. Available online: https:/ /www.ibm.com/downloads/cas/7MK5LPON (accessed on 21 October 2020).

65. Udovita, P.V.M.V.D. Conceptual Review on Dimensions of Digital Transformation in Modern Era. Int. J. Sci. Res. Publ. 2020, 10, 520-529. [CrossRef]

66. Mahraz, M.I.; Benabbou, L.; Berrado, A. A systematic literature review of digital transformation. In Proceedings of the International Conference on Industrial Engineering and Operations Management, Pilsen, Czech Republic, 23-26 July 2019; pp. 917-931.

67. Nasution, R.A.; Rusnandi, L.S.L.; Qodariah, E.; Arnita, D.; Windasari, N.A. The Evaluation of Digital Readiness Concept: Existing Models and Future Directions. Asian J. Technol. Manag. 2018, 11, 94-117. [CrossRef]

68. Hartley, J.L.; Sawaya, W.J. Tortoise, not the hare: Digital transformation of supply chain business processes. Bus. Horiz. 2019, 62, 707-715. [CrossRef]

69. Da Freitas, J.C.S.; Maçada, A.C.G.; Brinkhues, R.A.; Montesdioca, G.Z. Digital capabilities as key to digital business performance. In Proceedings of the AMCIS 2017-America's Conference on Information Systems: A Tradition of Innovation, Boston, MA, USA, 10-12 August 2017.

70. Cenamor, J.; Parida, V.; Wincent, J. How entrepreneurial SMEs compete through digital platforms: The roles of digital platform capability, network capability and ambidexterity. J. Bus. Res. 2019, 100, 196-206. [CrossRef]

71. Nguyen, T.H.; Newby, M.; Macaulay, M.J. Information technology adoption in small business: Confirmation of a proposed framework. J. Small Bus. Manag. 2015, 53, 207-227. [CrossRef]

72. Dellermann, D.; Lipusch, N.; Ebel, P. Developing Design Principles for a Crowd-Based Business Model Validation System. In Proceedings of the International Conference on Design Science Research in Information Systems Springer, Gallen, Switzerland, 4-5 June 2017; pp. 163-178.

73. Hagen, B.; Zucchella, A.; Cerchiello, P.; De Giovanni, N. International strategy and performance-Clustering strategic types of SMEs. Int. Bus. Rev. 2012, 21, 369-382. [CrossRef]

74. Kwon, E.H.; Park, M.J. Critical factors on firm's digital transformation capacity: Empirical evidence from Korea. Int. J. Appl. Eng. Res. 2017, 12, 12585-12596.

75. Verhoef, P.C.; Broekhuizen, T.; Bart, Y.; Bhattacharya, A.; Dong, J.Q.; Fabian, N.; Haenlein, M. Digital transformation: A multidisciplinary reflection and researce agenda. J. Bus. Res. 2019. [CrossRef]

76. Ulas, D. Digital Transformation Process and SMEs. Procedia. Comput. Sci. 2019, 158, 662-671. [CrossRef]

77. Sivadas, E.; Dwyer, F.R. An examination of organizational factors influencing new product success in internal and alliance-based processes. J. Mark. 2000, 64, 31-49. [CrossRef]

78. Beliaeva, T.; Ferasso, M.; Kraus, S.; Damke, E.J. Dynamics of digital entrepreneurship and the innovation ecosystem: A multilevel perspective. Int. J. Entrep. Behav. Res. 2019, 26, 266-284. [CrossRef]

79. $\mathrm{Wu}, \mathrm{J} . ; \mathrm{Wu}, \mathrm{Z}$. Integrated risk management and product innovation in China: The moderating role of board of directors. Technovation 2014, 34, 466-476. [CrossRef]

80. Nwankpa, J.K.; Roumani, Y. IT Capability and Digital Transformation: A Firm Performance Perspective. In ICIS Proceedings; Association for Information Systems: Dublin, Ireland, 2016; pp. 1-16.

81. Yoo, Y.; Henfridsson, O.; Lyytinen, K. Research Commentary-The New Organizing Logic of Digital Innovation: An Agenda for Information Systems Research. Inf. Syst. Res. 2010, 21, 724-735. [CrossRef]

82. Fitzgerald, M. How Starbucks Has Gone Digital. MIT Sloan Manag. Rev. 2013, 54, 1-8.

83. Kotarba, M. Digital transformation of business models. Found. Manag. 2018, 10, 123-142. [CrossRef]

84. Grönroos, C.; Voima, P. Critical service logic: Making sense of value creation and co-creation. J. Acad. Mark. Sci. 2013, 41, 133-150. [CrossRef]

85. Beckers, S.F.M.; van Doorn, J.; Verhoef, P.C. Good, better, engaged? The effect of company-initiated customer engagement behavior on shareholder value. J. Acad. Mark. Sci. 2017, 46, 366-383. [CrossRef] 
86. Andriole, S.J. Five myths about digital transformation. MIT Sloan Manag. Rev. 2017, 58, $20-22$.

87. Bharadwaj, A.; Sawy, O.A.; Pavlou, P.A.; Venkatraman, N. Digital business strategy: Toward a next generation of insights. Mis. Q. 2013, 37, 471-482. [CrossRef]

88. Newell, S.; Marabelli, M. Strategic opportunities (and challenges) of algorithmic decision-making: A call for action on the long-term societal effects of 'datification'. J. Strateg. Inf. Syst. 2015, 24, 3-14. [CrossRef]

89. Blocker, C.P.; Flint, D.; Myers, M.B.; Slater, S.F. Proactive customer orientation and its role for creating customer value in global markets. J. Acad. Mark. Sci. 2010, 39, 216-233. [CrossRef]

90. Fitzgerald, M.; Kruschwitz, N.; Bonnet, D.; Welch, M. Embracing digital technology: A new strategic imperative. 2013 Digital Transformation Global Executive Study and Research Project. MIT Sloan Manag. Rev. 2014, 55, 1.

91. Schwertner, K. Digital Transformation of Business. Trakia J. Sci. 2017, 15, 388-393. [CrossRef]

92. Porter, M.E.; Heppelmann, J.E. How Smart Connected Products Are Transforming Companies. Harv. Bus. Rev. 2015, 93, 98-114.

93. Oh, C.; Roumani, Y.; Nwankpa, J.K.; Hu, H.F. Beyond likes and tweets: Consumer engagement behavior and movie box office in social media. Inf. Manag. 2017, 54, 25-37. [CrossRef]

94. Christensen, C.M.; Raynor, M.; McDonald, R. What is disruptive innovation? Harv. Bus. Rev. 2015, 93, 44-53.

95. Habtay, S.R.; Holmén, M. Incumbents responses to disruptive business model innovation: The moderating role of technology vs. market-driven innovation. Int. J. Entrep. Innov. Manag. 2014, 18, 289-309. [CrossRef]

96. Kim, R.Y. The Impact of COVID-19 on Consumers: Preparing for Digital Sales. IEEE Eng. Manag. Rev. 2020, 48, 212-218. [CrossRef]

97. Milzam, M.; Mahardika, A.; Amalia, R. Corona Virus Pandemic Impact on Sales Revenue of Micro Small and Medium Enterprises (MSMEs) in Pekalongan City, Indonesia. J. Vocat. Stud. Appl. Res. 2020, 2, 7-10. Available online: https://ejournal2.undip.ac.id/ index.php/jvsar/article/download/7600/4028 (accessed on 5 November 2020).

98. Fabeil, N.F.; Pazim, K.H.; Langgat, J. The Impact of Covid-19 Pandemic Crisis on Micro-Enterprises: Entrepreneurs' Perspective on Business Continuity and Recovery Strategy. J. Econ. Bus. 2020, 3. [CrossRef]

99. Fairlie, R. The impact of COVID-19 on small business owners: Evidence from the first three months after widespread socialdistancing restrictions. J. Econ. Manag. Strategy 2020, 29, 727-740. [CrossRef]

100. Patel, J.; Malpani, A. Impact of Covid19 on e-marketing: An Early Stage Review. Int. J. Adv. Sci. Technol. 2020, 29. Available online: http://sersc.org/journals/index.php/IJAST/article/download/23918/12474/ (accessed on 5 November 2020).

101. Creswell, J.W. Qualitative Inquiry and Research Design: Choosing among Five Approaches, 3rd ed.; Sage Publishing: Thousand Oaks, CA, USA, 2013; pp. 69-110.

102. Windsor, D.W. Value Creation Theory: Literature Review and Theory Assessment. Stakehold. Manag. Bus. Soc. 2017, 1, 75-100. [CrossRef]

103. Eisenhardt, K.M.; Graebner, M.E. Theory building from cases: Opportunities and challenges. Acad. Manag. J. 2007, 50, 25-32. [CrossRef]

104. Sekaran, U.; Bougie, R. Reserach Methods for Bussiness—A Skill-Bulding Approach: Measurement-Scaling, Reliability and Validity, 7th ed.; John Wiley \& Sons: Chichester, UK, 2016; pp. 206-228.

105. Malhotra, N.K.; Nunan, D.; Birks, D.F. Marketing Research-An Applied Approach: Sampling: Design and Procedures, 5th ed.; Pearson: London, UK, 2017; pp. 411-441.

106. Crabtree, B.F.; Miller, W.L. A Template Approach to Text Analysis: Developing and Using Codebooks; Sage Publications: Newbury Park, CA, USA, 1992; pp. 93-109.

107. Peillon, S.; Dubruc, N. Barriers to digital servitisation in French manufacturing SMEs. Procedia CIRP 2019, 83, 146-150. [CrossRef]

108. Leeflang, P.S.; Verhoef, P.C.; Dahlström, P.; Freundt, T. Challenges and solutions for marketing in a digital era. Eur. Manag. J. 2014, 32, 1-12. [CrossRef]

109. Khin, S.; Ho, T.C. Digital technology digital capability and organisational performance: A mediating role of digital innovation. Int. J. Innov. Sci. 2019, 11, 177-195. [CrossRef] 